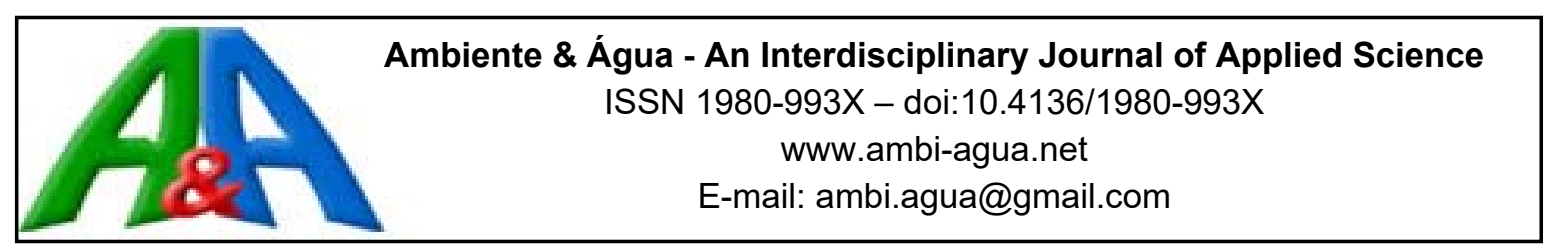

\title{
Evaluation of water-stress tolerance of Acala SJ 2 and Auburn 2 cotton cultivars in a phenotyping platform
}

\author{
doi:10.4136/ambi-agua.2105
}

Received: 03 Mar. 2017; Accepted: 05 Jun. 2017

\section{Cleber Morais Guimarães ${ }^{1 *}$; Luís Fernando Stone ${ }^{1}$; Giovani Greigh de Brito ${ }^{2}$; Jair Heuert ${ }^{3}$}

\author{
${ }^{1}$ Empresa Brasileira de Pesquisa Agropecuária (Embrapa) Arroz e Feijão, \\ Santo Antônio de Goiás, GO, Brasil \\ ${ }^{2}$ Empresa Brasileira de Pesquisa Agropecuária (Embrapa) Clima Temperado, \\ Pelotas, RS, Brasil \\ ${ }^{3}$ Empresa Brasileira de Pesquisa Agropecuária (Embrapa) Algodão, \\ Campina Grande, PA, Brasil \\ *Corresponding author: e-mail: cleber.guimaraes@embrapa.br, \\ luis.stone@embrapa.br, giovani.brito@embrapa.br, jair.heuert@embrapa.br
}

\begin{abstract}
Due to the current scarcity of water, which may be aggravated by climate changes, it is important to develop cultivars tolerant to water stress. For this, information regarding the variability of the tolerance of cultivars to this stress is required. This information can be obtained by using phenotyping platforms, which allow a large-scale and automated assessment of crop traits related to productivity under water stress. This study took place in a greenhouse and used a phenotyping platform to evaluate some agronomic and physiological traits of two cotton cultivars with differing tolerances to this stress. The experiment was performed in a randomized block design, in a split-plot scheme with four replicates. The main plots were composed of five water regimes and the subplots of two cultivars, Acala SJ 2 and Auburn 2. The water regimes consisted of a well-irrigated treatment (daily replacement of $100 \%$ of evapotranspired water) and four water restriction regimes $(20 \%, 40 \%, 60 \%$ and $80 \%$ of evapotranspired water at the well-irrigated treatment). The phenotyping platform and protocol (different percentages of daily replacement of evapotranspired water) employed were suitable to the evaluated cotton cultivars for water-stress tolerance, and allowed the determination of the cultivar most tolerant (Acala SJ 2) and of the cultivar most sensitive (Auburn 2) to water stress. 'Acala SJ 2' displayed better physiological and agronomic traits in all water regimes, including higher root density in the upper soil layer, as well as higher water use than 'Auburn 2', which explained its higher seed yield under the conditions employed.
\end{abstract}

Keywords: agronomic and physiological traits, Gossypium hirsutum L., irrigation protocol.

\section{Tolerância ao estresse hídrico das cultivares de algodão Acala SJ 2 e Auburn 2 avaliada em uma plataforma de fenotipagem}

\section{RESUMO}

Devido à atual escassez de água, que pode ser agravada pelas mudanças climáticas, é importante desenvolver cultivares tolerantes ao estresse hídrico. Para isso, são necessárias 
informações sobre a variabilidade das cultivares quanto à tolerância a esse estresse. Essas informações podem ser obtidas por meio de plataformas de fenotipagem, que permitem avaliação automatizada e em larga escala de características da cultura relacionadas com a produtividade sob estresse hídrico. Este trabalho foi desenvolvido em casa de vegetação e usou uma plataforma de fenotipagem para avaliar algumas características agronômicas e fisiológicas de duas cultivares de algodão que diferem em tolerância a esse estresse. O experimento foi realizado no delineamento de blocos ao acaso, em parcelas subdivididas, e com quatro repetições. Nas parcelas foram estabelecidos cinco regimes hídricos e nas subparcelas, duas cultivares: Acala SJ 2 e Auburn 2. Os regimes hídricos consistiram de um tratamento bem irrigado (reposição diária de $100 \%$ da água evapotranspirada) e quatro regimes de restrição hídrica $(20 \%, 40 \%, 60 \%$ e $80 \%$ de água evapotranspirada no tratamento bem irrigado). A plataforma de fenotipagem e o protocolo (diferentes porcentagens de reposição diária da água evapotranspirada) utilizados foram adequados para avaliar cultivares de algodão quanto à tolerância ao estresse hídrico, e permitiram discriminar a cultivar mais tolerante (Acala SJ 2) da mais sensível (Auburn 2). A 'Acala SJ 2' apresentou melhores características fisiológicas e agronômicas em todos os regimes hídricos, incluindo maior densidade de raízes na camada superior do solo e maior uso de água do que a 'Auburn 2', o que explicou sua maior produtividade.

Palavras-chave: características agronômicas e fisiológicas, Gossypium hirsutum L., protocolo de irrigação.

\section{INTRODUCTION}

Abiotic stresses are the major factors in global agricultural losses, and projected climate changes could increase their negative effects in the future (Weber et al., 2014; Brito et al., 2016). Even the most productive agricultural regions experience short periods of drought during almost any year and occasional years with severe droughts (Barnabás et al., 2008). Drought is thus one of the major limitations to agricultural production worldwide.

Cotton (Gossypium hirsutum L. r. latifolium) is the major fiber crop in the world; however, cotton yields are often limited due to the sensitivity of this crop to environmental stresses, such as temperature variation and drought (Brito et al., 2014b; Luo et al., 2016). Drought may result in reductions in yield of up to $30 \%$ compared to that of well-irrigated conditions, especially when the stress of drought occurs during flowering and fructification (Brito et al., 2011; B2014a). The quantity and the quality of the cotton fiber produced are directly related to the availability of water in the soil during the plant's phenological stages, especially during the initial reproductive phase. Drought during the fiber-elongation period results in decreased fiber length. Water stress after fiber elongation leads to fiber immaturity and low micronaire, a measure denoting fiber fineness and maturity (Selvam et al., 2009).

Currently, water availability for use in agriculture is increasingly limited and expensive and such water shortages may be aggravated by climate change. Increasing temperatures and the worsening distribution of rainfall is not unlikely, thus further restricting the planting potential of agricultural areas if remedial measures are not taken (Guimarães et al., 2016). As the world population continues to grow and water resources for crop production decline, the development of drought-tolerant cultivars and water-efficient crops is of global concern (Barnabás et al., 2008).

Cotton has genotypic variability for water-stress tolerance (Kar et al., 2005; Iqbal et al., 2011); nevertheless, there are few studies of the genetic mechanisms that control the droughttolerance variability of cotton (Selvam et al., 2009; Iqbal et al., 2011). In this context, basic 
information regarding the variability for tolerance to this stress and the heritability of this trait should be made available to plant breeders in order that they might develop elite breeding lines tolerant to water stress.

The capacity for precise phenotyping under reliable conditions probably represents the most limiting factor for the progress of genomic studies on drought tolerance. Great precision is required because the differences may be small and subtle, and detailed physiological measurements are difficult when many genotypes are involved (Araus and Cairns, 2014). Phenotyping platforms have therefore been developed aimed at accurate phenotyping, with large-scale and automated assessment. These platforms are useful tools for identifying agronomic and physiological traits that can be assessed in a fast and/or non-destructive manner and that have a strong correlation with crop yield under water-stress conditions.

The objective of this study was to evaluate the root density, seed yield per plant, plant height, number of nodes and bolls per plant, biomass of bolls and stems per plant, cumulative evapotranspiration per soil column and water potential, temperature and diffusive resistance of the leaves of two cotton cultivars with differing tolerances to water stress, in a greenhouse, using a phenotyping platform. We expected that the phenotyping platform and protocol (different percentages of daily replacement of evapotranspired water) employed would be suitable to the cotton cultivars evaluated for water-stress tolerance, and would allow us to determine the most tolerant (Acala SJ 2) and the most sensitive (Auburn 2) cultivar to water stress.

\section{MATERIAL AND METHODS}

The study was performed in a greenhouse from September 2014 to January 2015, at Embrapa Arroz e Feijão, in Santo Antônio de Goiás, GO, Brazil (16²7'28"S, 49¹9'52"W, at $823 \mathrm{~m}$ above sea level). The mean values of temperature and relative air humidity in the greenhouse were $27.6^{\circ} \mathrm{C}$ and $81.5 \%$, respectively.

A phenotyping platform for tolerance to water stress named "SITIS" (Figure 1) was used, which is a real-time automated control system for monitoring plant physiological parameters, soil moisture, greenhouse climate and irrigation of the soil columns. It is composed of 384 soil columns, packed in PVC pipes with a $0.25 \mathrm{~m}$ diameter and $1.00 \mathrm{~m}$ height, formed of five rings $0.20 \mathrm{~m}$ high connected by duct tape, and placed on digital scales with an irrigation point for each column. The amount of water used by the plants can be monitored in each column by the difference in weight.

The experiment was carried out in a randomized-block design, in a split plot scheme with four replicates, using 40 soil columns. The main plots were composed of five water regimes and the subplots of two cultivars, Acala SJ 2 and Auburn 2, which are considered drought tolerant and sensitive, respectively (Brito et al., 2014a). The water regimes consisted of a well-watered treatment (matric potential $\geq-0.035 \mathrm{MPa}$, measured with tensiometers installed at $0.10 \mathrm{~m}$ ) throughout the cycle and four water-stressed treatments. In these treatments, the well-watered condition was maintained until the opening of the first flower bud, phenological stage F1 (42 days after emergence), when water restriction regimes were applied for 66 days (until harvest) by daily replacement of $20 \%, 40 \%, 60 \%$ and $80 \%$ of evapotranspired water at the well-watered treatment (daily replacement of $100 \%$ of evapotranspired water). Evapotranspiration was monitored by the difference of consecutive readings of the weight of columns, measured with digital scales.

A clayey Acric Red Latosol (Oxisol) was used, and according to its chemical analysis and crop requirements in greenhouse conditions, $12 \mathrm{~g}$ per column of the commercial fertilizer 5-30-15 ( $3 \mathrm{~g}$ in the sowing furrow and $9 \mathrm{~g}$ incorporated into the $0.10 \mathrm{~m}$ soil depth) were applied. Also, $17 \mathrm{~g}$ per column of simple superphosphate and $15 \mathrm{~g}$ per column of lime were applied, and 
incorporated into a $0.10 \mathrm{~m}$ soil depth. Ten seeds were sown per column and were thinned seven days after emergence, leaving one plant per column. Eleven days after emergence, $1 \mathrm{~mL} \mathrm{~L}^{-1}$ of the growth inhibitor Sponsor was applied.

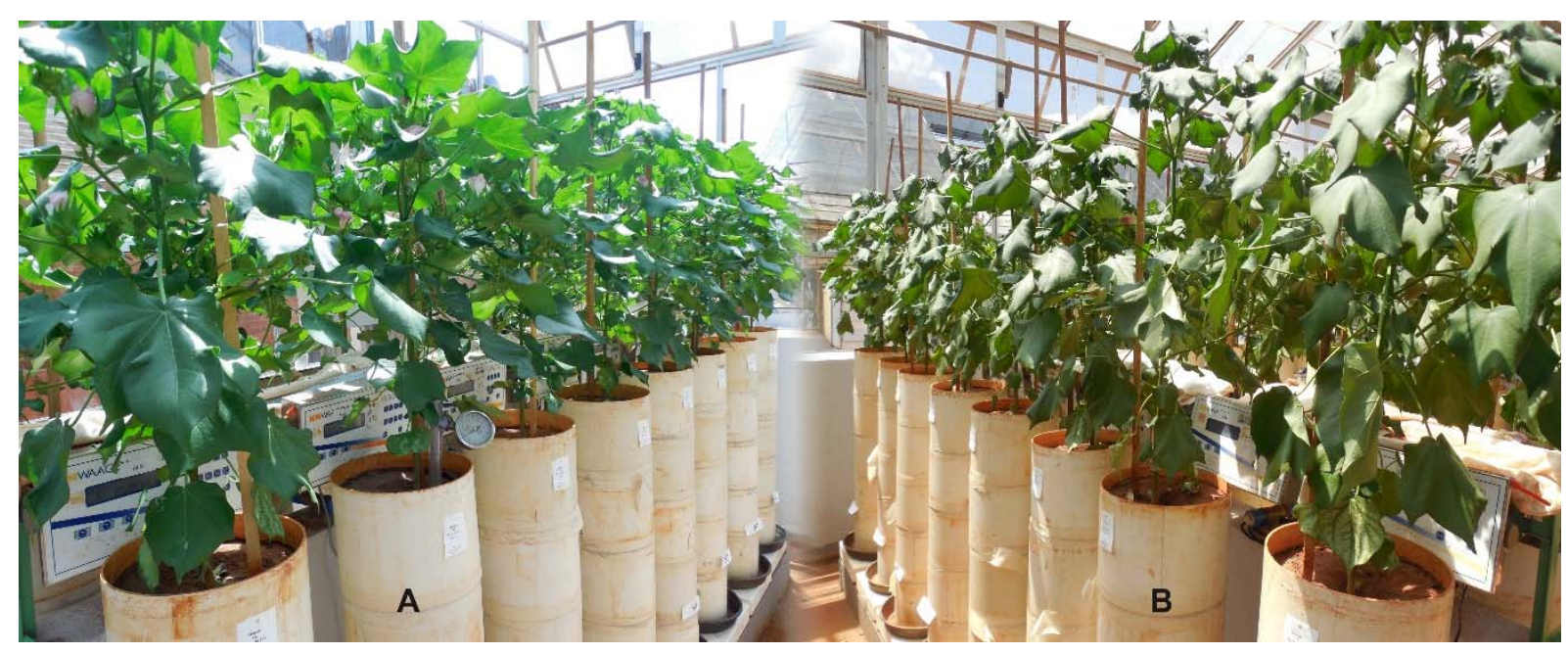

Figure 1. Soil columns on digital scales with cotton plants under well-watered conditions (A) and under water stress (B) at the SITIS phenotyping platform.

The root system was evaluated at the time of seed harvest, 108 days after emergence, in soil layers between $0.20 \mathrm{~m}$ to $1.00 \mathrm{~m}$ from the surface. The separation of the roots from the soil samples was performed by the method of repeated suspension/decantation. After separation, the roots were recovered from the supernatant in $0.25 \mathrm{~mm}$ sieves with a tweezer, and taken to a forced air-circulating oven at $85^{\circ} \mathrm{C}$ until a constant weight was obtained, to determine their dry-matter weight. The root density was obtained by dividing the dry root biomass, in $\mathrm{mg}$, by the soil sample volume (soil column area $x 0.20 \mathrm{~cm}$ ), in $\mathrm{cm}^{3}$. The seed yield per plant, plant height, number of nodes and bolls per plant, biomass of bolls and stems per plant, and the cumulative evapotranspiration were also determined after F1 stage (from 42 to 108 days after emergence) for each soil column, as well as the water potential, temperature and diffusive resistance of the leaves. The last three traits were measured on the superior surface of two apical leaves fully expanded and with good solar exposure, between $13 \mathrm{~h} 00$ and 14h00, at 65, 70 and 85 days after emergence, in all subplots of two replicates. The leaf diffusive resistance was measured with a Decagon porometer, Model CS-1. The leaf water potential was determined using a pressure chamber, Soil Moisture Equipment, Model 3005, and the equipment was installed near the experiment to minimize the time between sample collection and readings of the leaf water potential. Precautions with the manometer calibration and with the correct seal were taken to avoid gas escape. The leaf temperature was measured with a Fluke Model 66 infrared thermometer.

The analysis of variance and regression were performed for seed yield per plant, plant height, number of nodes and bolls per plant, boll and stem biomass per plant and cumulative evapotranspiration per soil column. For the other variables, only regression equations were adjusted since they were evaluated just in two replicates. For all analysis, SAS software (SAS Institute, Cary, NC, USA) was used. 


\section{RESULTS AND DISCUSSION}

Water regimes and cultivars significantly affected all assessed agronomic components. The interaction between these factors was significant only for the biomass of stems (Table 1).

Table 1. Summary of the analysis of variance for seed yield per plant (Yield), plant height (Height), number of nodes per plant (Node), number of bolls per plant (Boll), biomass of bolls per plant (Bioboll), biomass of stems per plant (Biostem) and cumulative evapotranspiration per soil column (ET).

\begin{tabular}{lcccccccc}
\hline Source of variation & DF & \multicolumn{7}{c}{ Mean square } \\
\hline & & Yield (g) & Height $(\mathrm{cm}$ & Node $\left(\mathrm{n}^{\mathrm{o}}\right)$ & Boll $\left(\mathrm{n}^{\mathrm{o}}\right)$ & Bioboll $(\mathrm{g})$ & Biostem $(\mathrm{g})$ & ET (L) \\
\hline Block & 3 & $289.5^{*}$ & $107.7^{\mathrm{ns}}$ & $0.1^{\mathrm{ns}}$ & $9.1^{*}$ & $23.6^{\mathrm{ns}}$ & $24.0^{\mathrm{ns}}$ & $673.8^{* *}$ \\
Water regime (WR) & 4 & $4743.8^{* *}$ & $2558.9^{* *}$ & $56.0^{* *}$ & $124.7^{* *}$ & $411.6^{* *}$ & $1156.8^{* *}$ & $4319.5^{* *}$ \\
Error a & 12 & 73.9 & 79.1 & 1.1 & 1.7 & 26.4 & 27.9 & 44.6 \\
Cultivar (C) & 1 & $94.4^{* *}$ & $2958.4^{* *}$ & $15.6^{*}$ & $160.0^{* *}$ & $115.4^{*}$ & $1128.4^{* *}$ & $2425.5^{* *}$ \\
C x WR & 4 & $116.0^{\mathrm{ns}}$ & $204.5^{\mathrm{ns}}$ & $1.8^{\mathrm{ns}}$ & $6.6^{\mathrm{ns}}$ & $46.0^{\mathrm{ns}}$ & $81.7^{* *}$ & $101.9^{\mathrm{ns}}$ \\
Error b & 15 & 76.9 & 96.8 & 2.4 & 4.1 & 20.9 & 16.3 & 53.8 \\
\hline CVa (\%) & & 19.0 & 10.2 & 6.3 & 13.5 & 30.0 & 15.2 & 10.4 \\
CVb (\%) & & 19.4 & 11.2 & 9.3 & 20.9 & 26.7 & 11.6 & 11.4 \\
\hline $\mathrm{Note} \%$
\end{tabular}

Note: ${ }^{\mathrm{ns}}=$ not significant, ${ }^{*}$ and $* *=$ significant at 5 and $1 \%$ probability $(\mathrm{p}<0.05$ and $\mathrm{p}<0.01)$.

Seed yield per plant was 49.9 and $40.4 \mathrm{~g}$, plant height 96.1 and $78.9 \mathrm{~cm}$, number of nodes per plant 17.4 and 15.8, number of bolls per plant 11.7 and 7.7, biomass of bolls per plant 18.8 and 15.5 and biomass of stems 40.1 and $29.4 \mathrm{~g}$ for Acala SJ 2 and Auburn 2 cultivars, respectively. Therefore, Acala SJ 2 cultivar showed better agronomic traits than Auburn 2 cultivar in all water regimes.

The average seed yield of both cultivars decreased with increasing water deficit according to a quadratic mathematical model (Figure 2A). The yield losses were, on average, $28.0 \%$, $49.9 \%, 65.60 \%$ and $75.1 \%$ in the water regimes of $80 \%, 60 \%, 40 \%$ and $20 \%$ of evapotranspiration replacement, respectively.

Cotton yields are often limited due to the sensitivity of this crop to environmental stresses, such as temperature variation and drought, as highlighted by this study. In this sense, even when $80 \%$ of evapotranspired water was replaced, seed yield decreased by about $28.0 \%$. To analyze the effects of water deficit on cotton seed yield, it is necessary to consider that this yield is determined by a combination of many components, including boll number, boll size, seed number per boll and fiber cell per seed. These components can be influenced by plant physiological and environmental interaction. The decrease in seed yield with increasing water restrictions verified in this study can be attributed to the effect of water stress on yield components, as described below, corroborating the results of Ullah et al. (2008), Levi et al. (2009), and Brito et al. (2011, 2014a). 
Plant height was reduced with increasing water stress according to a quadratic equation (Figure 2B). On average, the reductions were 20.2\%, 32.5\%, 36.9\% and 33.6\%, in water regimes of $80 \%, 60 \%, 40 \%$ e $20 \%$ of evapotranspiration replacement, respectively. Other reports also observed that water stress reduced the overall plant stature of cotton (Baldo et al., 2009; Ferreira et al., 2013). According to the first authors, this occurred concomitantly with a $35 \%$ reduction in leaf-area index, prompting an $8 \%$ reduction in solar radiation interception.
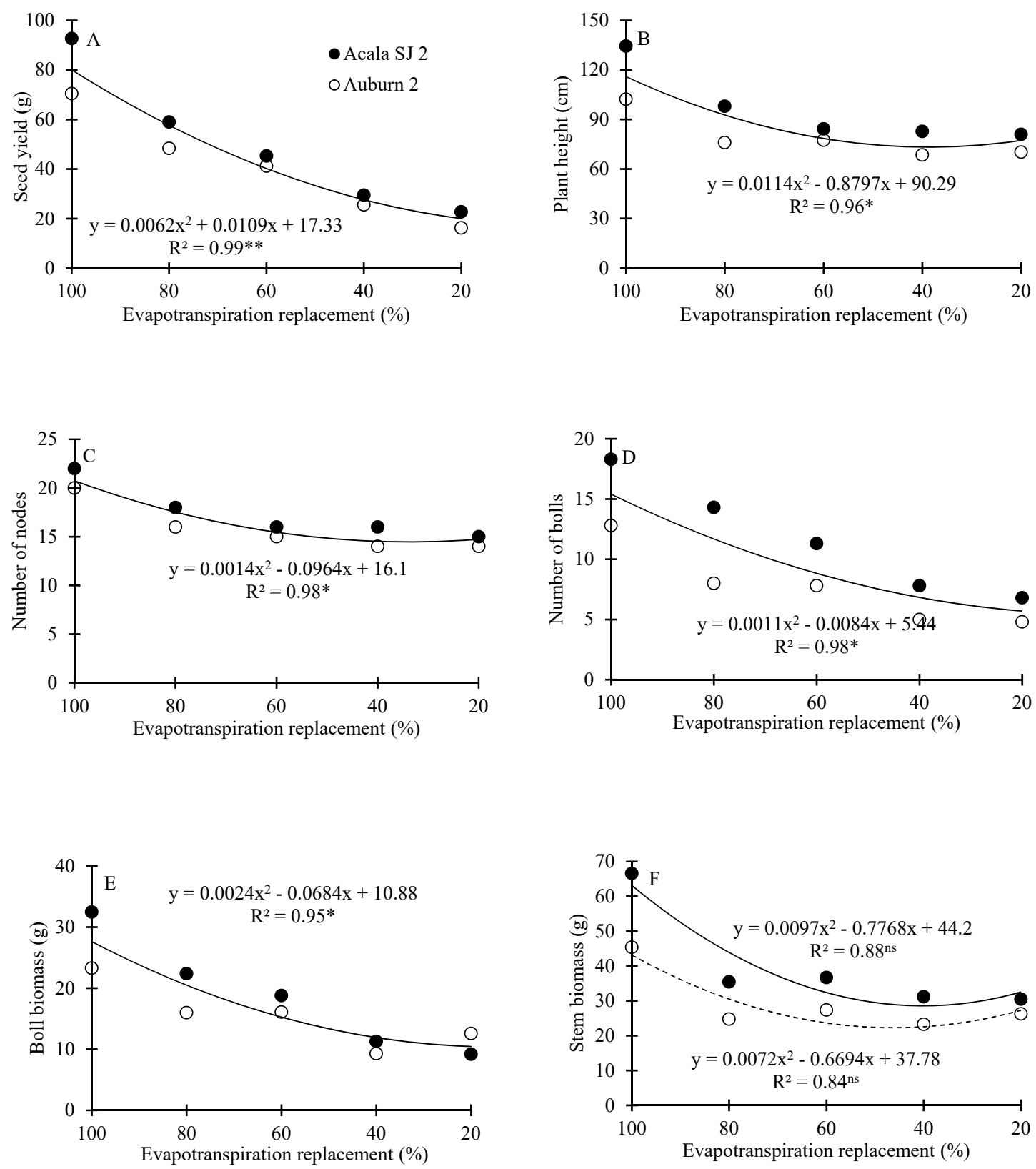

Figure 2. Average seed yield, plant height, number of nodes and bolls per plant and biomass of bolls and stems per plant of Acala SJ $2(\bullet)$ and Auburn $2(\circ)$ cotton cultivars as a function of evapotranspiration replacement.

Note: ${ }^{\mathrm{ns}}=$ not significant, ${ }^{*}$ and $* *=$ significant at 5 and $1 \%$ probability $(\mathrm{p}<0.05$ and $\mathrm{p}<0.01)$. 
The response of the number of plant nodes to water regimes was also explained by a quadratic equation (Figure 2C). Water regimes of $80 \%, 60 \%, 40 \%$ and $20 \%$ of evapotranspiration replacement caused reductions of $15.2 \%, 24.9 \%, 29.2 \%$ and $28.0 \%$, respectively. Kawakami et al. (2010) also found that water-stressed cotton plants exhibited a significantly lower number of nodes than well-watered plants. This reduction was related to the decrease in height, since, according to Singh et al. (2006), the number of nodes decreases with decreasing plant height. According to these authors, the number of nodes appeared to play an important role for increasing the fruiting branches and the total number of bolls.

The response of the number of bolls to water regimes also followed a quadratic mathematical model (Figure 2D). Water regimes of $80 \%, 60 \%, 40 \%$ and $20 \%$ of evapotranspiration replacement caused reductions of $24.3 \%, 43.0 \%, 56.0 \%$ and $63.4 \%$, respectively. Baldo et al. (2009) also observed reduction in the number of bolls with water stress. According to Krieg and Sung (1986), the overall strategy adopted by cotton for survival during water stress seems to support the development of few bolls over total fruit retention.

Boll biomass was reduced with increasing water stress according to a quadratic equation (Figure 2E). On average, the reductions were 25.9\%, 45.0\%, 57.3\% and 62.7\%, in water regimes of $80 \%, 60 \%, 40 \%$ and $20 \%$ of evapotranspiration replacement, respectively. Baldo et al. (2009) also observed a reduction in the boll biomass with water stress, and suggested that this stress in the floral bud stage significantly affects the production of the reproductive structures of cotton.

The stem biomass of the Acala SJ 2 cultivar was higher in all water regimes, compared to the Auburn 2 cultivar (Figure 2F). Stem biomasses of 66.6, 35.5, 36.7, 31.2 and $30.5 \mathrm{~g}$ were observed in the Acala SJ 2 cultivar and of 45.4, 24.8, 27.4, 23.3 and $26.3 \mathrm{~g}$ in the Alburn 2 cultivar, in water regimes of $100 \%, 80 \%, 60 \%, 40 \%$ and $20 \%$ of evapotranspiration replacement, respectively.

The response of the stem biomass of both cultivars to water regimes did not significantly fit a linear or polynomial model (Figure 2F). Regarding the replacement of $100 \%$ of evapotranspiration, there were reductions in biomass ranging from $45 \%$ to $54 \%$ and from $40 \%$ to $49 \%$, for the Acala SJ 2 and the Auburn 2 cultivars, respectively. Wang et al. (2007), Ullah et al. (2008) and Baldo et al. (2009) also found that the total dry weight of cotton reduced as water stress increased. In addition, Ullah et al. (2008) found a positive correlation between cotton seed yield (CSY) and biological yield (BY) under water stress, indicating that BY is also a primary determinant of CSY under water stress and genetic improvement of BY in a waterlimited environment may also improve CSY.

The root density decreased from the surface until about $50 \mathrm{~cm}$ deep, where significantly smaller values occurred (Figure 3). From this depth, there was a tendency for the root density to increase in the soil deeper layers in all water regimes, due to the barrier provided by the bottom of the columns. The average root densities of the Acala SJ 2 cultivar in the upper soil layer, $0-20 \mathrm{~cm}$, were higher when compared to those observed for the Auburn 2 cultivar in all water regimes, except in the treatment with replacement of $60 \%$ of evapotranspired water. Average root densities of 0.62 and $0.54 \mathrm{mg} \mathrm{cm}^{-3}$ were observed along the soil profile for the Acala SJ 2 and Auburn 2 cultivars with 100\% of evapotranspiration replacement, respectively. These values were about $10 \%$ higher than the mean values showed in the four water-restriction regimes, 0.55 and $0.50 \mathrm{mg} \mathrm{cm}^{-3}$, respectively. Baldo et al. (2009) also found reductions in cotton root weight and root number with water stress. 

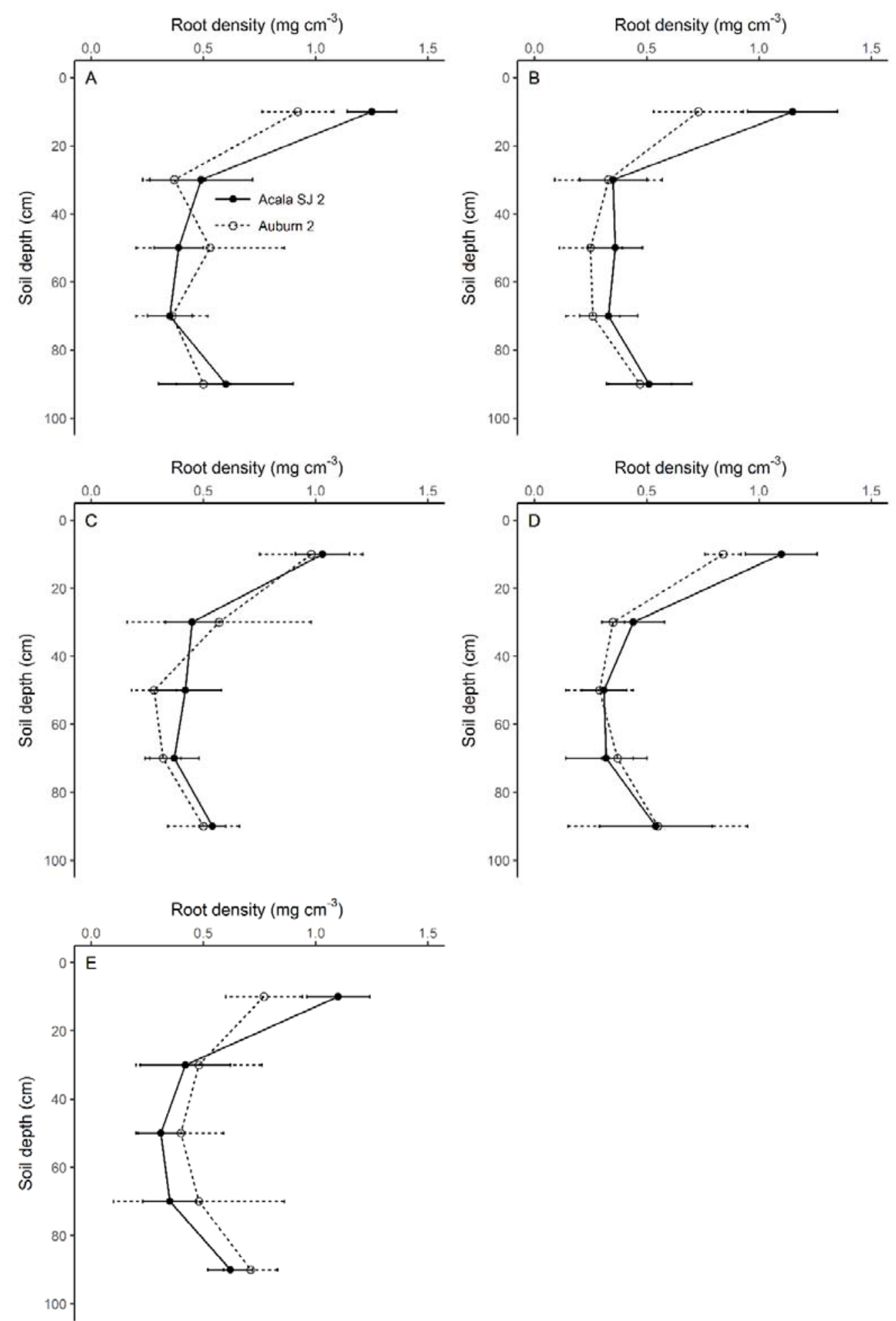

Figure 3. Root density from the surface to a $1.00 \mathrm{~m}$ depth of Acala SJ $2(\bullet)$ and Auburn $2(\circ)$ cotton cultivars as a function of evapotranspiration replacement: (A) $100 \%$, (B) $80 \%$, (C) $60 \%$, (D) $40 \%$, and (E) $20 \%$. Horizontal bars represent the standard deviation.

The leaf water potential of both cultivars decreased linearly with increasing water stress (Figure 4A). The Acala SJ 2 cultivar maintained higher leaf water potential compared to the Auburn 2 cultivar and the difference between them increased with increasing water stress, inferring that the root system of Acala SJ 2 cultivar, due to its higher density, as discussed 
previously, is more efficient in replacing evapotranspired water during times of the day with higher atmospheric water demand.
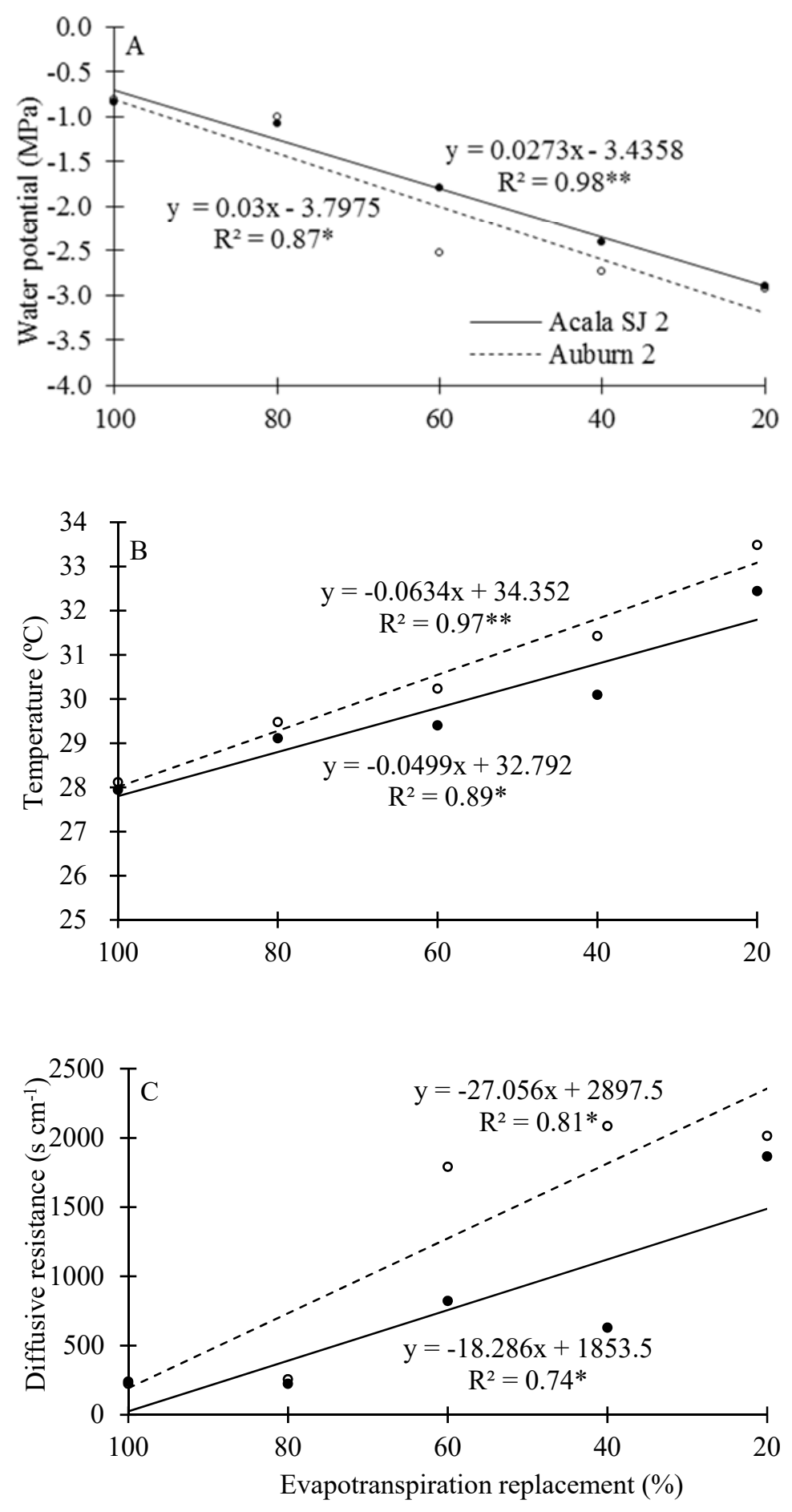

Figure 4. Water potential, temperature and diffusive resistance of the leaves of Acala SJ $2(\bullet)$ and Auburn 2 (०) cotton cultivars as a function of evapotranspiration replacement.

Note: $*$ and $* *=$ significant at 5 and $1 \%$ probability $(\mathrm{p}<0.05$ and $\mathrm{p}<0.01)$. 
Brito et al. (2011) found that cotton genotypes considered sensitive reached a leaf water potential of $-3.0 \mathrm{MPa}$ at predawn in the $16^{\text {th }}$ day after the suspension of irrigation. However, a tolerant genotype reached this foliar water status 18 days after the suspension of irrigation. After re-irrigation, the tolerant genotype recovered $50 \%$ of leaf water potential in about 3 hours, while the sensitive genotypes recovered 6 hours after re-irrigation. According to those authors, the timing of the progression of drought and the ability of plants to recover after being subjected to short and/or prolonged periods of drought are closely related to crop yield, when considering that processes such as cell expansion, gas exchange, and photochemical efficiency of photosystem II are affected by increasing water deficit. The reduction in osmotic potential is a consequence of the net accumulation of solutes in the symplast, resulting in an increase in the rate of reducing sugar in response to reduced water potential (Marur, 1999).

As might be expected, there was an increase in leaf temperature with increasing water stress (Figure 4B) because of stomatal closure and reduced transpiration. The water passing from the liquid to the gas phase removes heat from the surroundings, inducing cooling; but with stomata closure, such cooling does not occur. Linear mathematical models in both cultivars described this increase.

The leaf temperature of the Acala SJ 2 cultivar remained lower than the Auburn 2 cultivar at all water regimes (Figure 4B), suggesting more intense transpiration and better water status of the plants, which can be explained by a greater soil water uptake capacity or some mechanism of water-use restraint. Wang et al. (2007), under water-stress conditions from the initial reproductive growth stage of cotton, found that the transpiration ability decreased while the leaf temperature increased.

The leaf diffusive resistance also increased linearly with the intensity of water deficit (Figure 4C). Between 13:00 h and 14:00 h, when plants are under intense solar radiation and therefore under high atmospheric water demand, the Acala SJ 2 cultivar showed lower leaf diffusive resistances compared to those observed in the Auburn 2 cultivar. This suggests that the Acala SJ 2 cultivar had less limitation for transpiration, and was therefore under better water status, as previously discussed.

Ullah et al. (2008) found that water stress significantly reduced cotton stomatal conductance. They also observed a positive association between stomatal conductance and photosynthetic rate under water stress, which indicates a major role of stomatal effects in regulating leaf photosynthesis under water limited conditions, and a positive association between stomatal conductance and transpiration rate under well-watered and water stress conditions, indicating the prevalence of stomatal control of transpiration. Agreeing with these authors, Levi et al. (2009) stated that reduced $\mathrm{CO}_{2}$ diffusion due to decreased stomatal and mesophyll conductances has been identified as the predominant factor limiting net $\mathrm{CO}_{2}$ assimilation by cotton under drought conditions. The sum of the diffusion resistances sets the limit for photosynthesis rates in stressed leaves.

The average cumulative evapotranspiration from the F1 stage to harvest (from 42 to 108 days after emergence) was higher for the soil columns with Acala SJ 2 cultivar and decreased linearly with increasing water stress for both cultivars (Table 1 and Figure 5). As the plants totally covered the soil in the columns at that stage, transpiration accounted for most of the water lost to the atmosphere. Ullah et al. (2008) found that the transpiration rate of cotton was significantly reduced by water stress.

The Acala SJ 2 cultivar, besides showing greater water use, also showed better seed yield and biomass accumulation, as previously discussed. Zain et al. (2014) observed that the transpiration rate was positively correlated with the photosynthetic rate and rice grain yield. Decrease in photosynthetic rate under water stress leads to source-sink (fruiting bodies) 
imbalances and hormonal changes, which in turn causes flower bud shedding, and a reduction in the boll size and the fiber quality of cotton (Guinn et al., 1990).

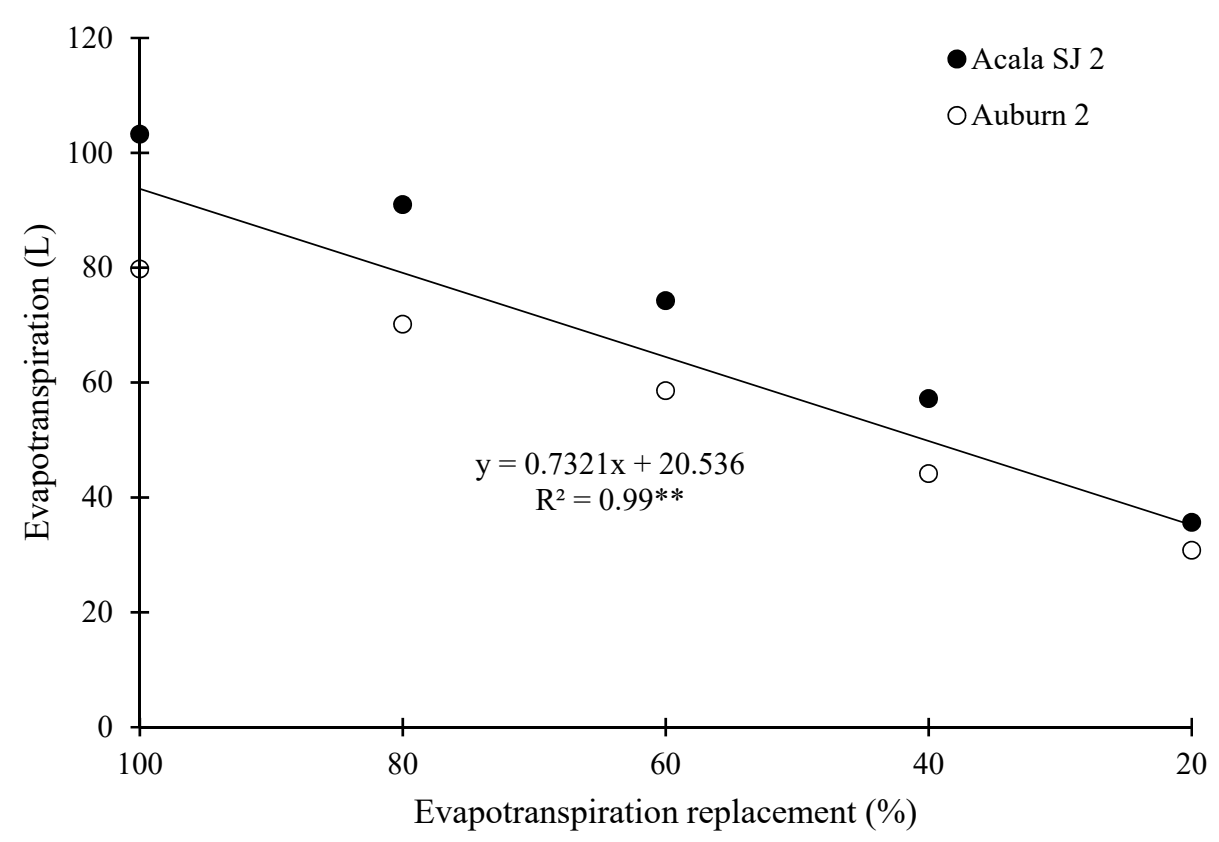

Figure 5. Average cumulative evapotranspiration of Acala SJ 2 and Auburn 2 cotton cultivars per soil column as a function of evapotranspiration replacement.

Note: $* *=$ significant at $1 \%$ probability $(\mathrm{p}<0.01)$.

The Acala SJ 2 cultivar maintained higher leaf-water potential and lower values for leafwater temperature and leaf-diffusive resistance when compared to the Auburn 2 cultivar. Additionally, Acala SJ 2 showed higher root density in the upper soil layer, where the majority of roots are. Taken together, these data can help to explain the higher seed yield showed by this cultivar. The data indicate a significant contribution of some root-functional and/or morphometric parameter involved in the lower stomatal resistance showed by Acala SJ 2. As has been shown for wheat and other species, water deficiency commonly leads to an increase in stomata resistance and a decrease in accumulated transpiration and aerial biomass accumulation (Elazab et al., 2012).

Ullah et al. (2008) observed that photosynthetic rate was significantly correlated with seed cotton yield and biomass under water stress; however, the level of these associations was not significant in well-watered conditions. These findings demonstrate that the association of the photosynthetic rate with yield is effective under a water-limited environment and may be useful as a selection criterion in breeding programs with the objective of improving drought tolerance and seed cotton yield under water-limited environments.

Since biomass production is tightly linked to transpiration, Blum (2009) stated that breeding for maximized soil moisture capture for transpiration is the most important target for yield improvement under water stress.

Considering future climate-change scenarios, plant breeders and physiologists should concentrate their efforts on establishing plant ideotypes for specific target environments, taking care to develop plants that not only survive under abiotic stresses, but that are also stable and productive in these environments. 


\section{CONCLUSIONS}

The phenotyping platform and protocol employed were suitable to the cotton cultivars evaluated for tolerance to water stress, and allowed the determination of the cultivars most tolerant (Acala SJ 2) and most sensitive (Auburn 2) to water stress.

The Acala SJ 2 cultivar displayed better physiological and agronomic traits in all water regimes, including higher root density in the upper soil layer, as well as higher water use than the Auburn 2 cultivar, which explained its higher seed yield under the conditions employed.

\section{REFERENCES}

ARAUS, J. L.; CAIRNS, J. E. Field high-throughput phenotyping: the new crop breeding $\begin{array}{lllllll}\text { frontier. Trends in Plant Science, v. 19, p. 52-61, } 2014 . & \text {. }\end{array}$ http://dx.doi.org/10.1016/j.tplants.2013.09.008

BALDO, R.; SCALON, S. de P. Q.; ROSA, Y. B. C. J.; MUSSURY, R. M.; BETONI, R.; BARRETO, W. dos S. Comportamento do algodoeiro cultivar Delta Opal sob estresse hídrico com e sem aplicação de bioestimulante. Ciência e Agrotecnologia, v. 3, p. 18041812, 2009. http://dx.doi.org/10.1590/S1413-70542009000700018

BARNABÁS, B.; JÄGER, K.; FEHÉR, A. The effect of drought and heat stress on reproductive processes in cereals. Plant, Cell and Environment, v. 31, p. 11-38, 2008. http://dx.doi.org/10.1111/j.1365-3040.2007.01727.x

BLUM, A. Effective use of water (EUW) and not water-use efficiency (WUE) is the target of crop yield improvement under drought stress. Field Crops Research, v. 112, p. 119-123, 2009. http://dx.doi.org/10.1016/j.fcr.2009.03.009.

BRITO, G. G. de; SUASSUNA, N. D.; DIOLA, V.; SOFIATTI, V.; DUCATTI, C.; SILVA, E. T. da; et al. Carbon isotope fractionation for cotton genotype selection. Pesquisa Agropecuária Brasileira, v. 49, p. 673-682, 2014a. http://dx.doi.org/10.1590/S0100204X2014000900003

BRITO, G. G. de; FERREIRA, A. C. de B.; BORIN, A. L. D. C. Ethylene inhibitors increase net assimilation rate and cotton boll dry matter under drought. Journal of Agricultural Science, v. 6, p. 197-206, 2014b. http://dx.doi.org/10.5539/jas.v6n10p197

BRITO, G. G. de; FAGUNDES, P. R. R.; TEló, G. M.; ABREU, A. G.; MAGAlhÃES JÚNIOR, A. M. de; FRANCO, D. F. et al. Impact of supra-optimal temperatures on physiology and yield in rice field. Journal of Agricultural Science, v. 8, p. 27-37, 2016. http://dx.doi.org/10.5539/jas.v8n2p27

BRITO, G. G. de; SOFIATTI, V.; LIMA, M. M. de A.; CARVALHO, L. P. de; SILVA FILHO, J. L da. Physiological traits for drought phenotyping in cotton. Acta Scientiarum. Agronomy, v. 33, p. 117-125, 2011. http://dx.doi.org/10.4025/actasciagron.v33i1.9839

ELAZAB, A.; MOLERO, G.; SERRET, M. D.; ARAUS, J. L. Root traits and $\delta^{13} \mathrm{C}$ and $\delta^{18} \mathrm{O}$ of durum wheat under different water regimes. Functional Plant Biology, v. 39, p. 379-393, 2012. http://dx.doi.org/10.1071/FP11237 
FERREIRA, A. C. de B.; LAMAS, F. M.; BRITO, G. G. de; BORIN, A. L. D. C. Water deficit in cotton plant originated from seeds treated with growth regulator. Pesquisa Agropecuária Tropical, v. 43, p. 417-423, 2013. http://dx.doi.org/10.1590/S198340632013000400011

Guimarães, C. M.; CASTRO, A. P. de; STONE, L. F.; OliVEIRA, J. P. de. Drought tolerance in upland rice: identification of genotypes and agronomic characteristics. Acta Scientiarum. Agronomy, v. 38, p. 201-206, 2016. http://dx.doi.org/10.4025/ actasciagron.v38i2.27164

GUINN, G.; DUNLAP, J. R.; BRUMMETT, D. L. Influence of water deficits on the abscisic acid and indole-3-acetic acid contents of cotton flower buds and flowers. Plant Physiology, v. 93, p. 1117-1120, 1990. http://dx.doi.org/10.1104/pp.93.3.1117.

IQBAL, K.; AZHAR, F. M.; KHAN, I. A.; EHSAN-ULLAH. Variability for drought tolerance in cotton (Gossypium hirsutum) and its genetic basis. International Journal of Agriculture \& Biology, v. 13, p. 61-66, 2011.

KAR, M.; PATRO, B. B.; SAHOO, C. R.; HOTA, B. Traits related to drought resistance in cotton hybrids. Indian Journal of Plant Physiology, v. 10, p. 377-380, 2005.

KAWAKAMI, E. M.; OOSTERHUIS, D. M.; SNIDER, J. L. Physiological effects of 1methylcyclopropene on well-watered and water-stressed cotton plants. Journal of Plant Growth Regulation, v. 29, p. 280-288, 2010. http://dx.doi.org/10.1007/s00344-0099134-3

KRIEG, D. R.; SUNG, J. F. M. Source-sink relations as affected by water stress during boll development. In: MAUNEY, I. R.; STEWART, J. M. (Eds.). Cotton physiology. Memphis: Cotton Foundation, 1986. p. 73-77.

LEVI, A.; OVNAT, L.; PATERSON, A. H.; SARANGA, Y. Photosynthesis of cotton nearisogenic lines introgressed with QTLs for productivity and drought related traits. Plant Science, v. 177, p. 88-96, 2009. http://dx.doi.org/10.1016/j.plantsci.2009.04.001.

LUO H.; MEROPE, T.; ZHANG, Y.; ZHANG, W. Combining gas exchange and chlorophyll a fluorescence measurements to analyze the photosynthetic activity of drip-irrigated cotton under different soil water deficits. Journal of Integrative Agriculture, v. 15, p. 1256-1266, 2016. http://dx.doi.org/10.1016/S2095-3119(15)61270-9.

MARUR, C. J. Curvas pressão-volume e expansão foliar em cultivares de algodoeiro submetidos à déficit hídrico. Scientia Agricola, v. 56, p. 563-569, 1999. http://dx.doi.org/10.1590/S0103-90161999000300008

SELVAM, J. N.; KUMARAVADIVEL, N.; GOPIKRISHNAN, A.; KUMAR, B. K.; RAVIKESAVAN, R.; BOOPATHI, M. N. Identification of a novel drought tolerance gene in Gossypium hirsutum L. cv KC3. Communications in Biometry and Crop Science, v. 4, p. 9-13, 2009.

SINGH, V.; PALLAGHY, C. K.; SINGH, D. Phosphorus nutrition and tolerance of cotton to water stress: I. Seed cotton yield and leaf morphology. Field Crops Research, v. 96, p. 191-198, 2006. http://dx.doi.org/10.1016/j.fcr.2005.06.009. 
ULLAH, I.; MEHBOOB-UR-RAHMANA; ASHRAF, M.; ZAFAR, Y. Genotypic variation for drought tolerance in cotton (Gossypium hirsutum L.): Leaf gas exchange and productivity. Flora, v. 203, p. 105-115, 2008. http://dx.doi.org/10.1016/j.flora. 2007.12.001.

WANG, C.; ISODA, A.; LI, M.; WANG, D. Growth and eco-physiological performance of cotton under water stress conditions. Agricultural Sciences in China, v. 6, p. 949-955, 2007. http://dx.doi.org/10.1016/S1671-2927(07)60133-3.

WEBER, R. L. M.; WIEBKE-STROHM, B.; BREDEMEIER, C.; MARGIS-PINHEIRO, M.; BRITO, G. G. de; RECHENMACHER, C. et al. Expression of an osmotin-like protein from Solanum nigrum confers drought tolerance in transgenic soybean. BMC Plant Biology, v. 14, p. 1-9, 2014. http://dx.doi.org/10.1186/s12870-014-0343-y

ZAIN, N. A. M.; ISMAIL, M. R.; PUTEH, A.; MAHMOOD, M.; ISLAM, M. R. Impact of cyclic water stress on growth, physiological responses and yield of rice (Oryza sativa L.) grown in tropical environment. Ciência Rural, v. 44, p. 2136-2141, 2014. http://dx.doi.org/10.1590/0103-8478cr20131154 